\title{
SOME STUTIES ON BACTERIOLOGICAL CAUSES OF ENTERITIS IN NEWLY
} BORNE CALVES

\author{
AZHAR M. HASSAN
}

Animal Health Research Institute Assuit, Egypt.

\begin{tabular}{|c|c|}
\hline & ABSTRACT \\
\hline Received at: $15 / 3 / 2012$ & $\begin{array}{l}\text { This study was initiated to isolation and identification of } \\
\text { probable bacterial causes in the fecal samples of newly born } \\
\text { calves suffering from enteritis in some farms of Assiut } \\
\text { Governorate A total number of } 80 \text { calves were subjected to the } \\
\text { study. These animals were randomly selected from some } \\
\text { Assiut farms. Twenty-five calves were considered as the } \\
\text { control group. These animals aged from one day to one month } \\
\text { suffering from sever diarrhea, increase of body temperature } \\
\text { (average } 40.5^{\circ} \mathrm{C} \text { ) and increase in heart rate. Some calves have } \\
\text { had loss of appetite, dehydration and dullness. Fifty- five } \\
\text { diseased calves were classified according to its age into four } \\
\text { groups, the first group included fourteen calves aged } 1-5 \text { days } \\
\text { old, second group included sixteen calves aged from } 6-10 \text { days } \\
\text { old, third group included twelve calves aged from } 11-15 \text { days } \\
\text { old and the fourth group included thirteen calves aged from } \\
16-30 \text { days old. The bacteriological examination reveald that } \\
\text { the incidence of enteric bacterial isolates in apparently healthy } \\
\text { calves was } 72 \% \text { and it was lower than in diseased calves } \\
\text { (100\%). It is clear that the incidence of enteric bacteria was } \\
100 \% \text { in all fecal samples. There were a wide range of bacteria } \\
\text { isolates from feacal samoles of both apparently healthy and } \\
\text { diseased calves. The isolates were Escherichia coli (O157) } \\
\text { from diseased calves in all four groups with different } \\
\text { percentages ( } 64.28 \% \text {, } 50 \%, 33.33 \% \text { and } 23.07 \%) \text { respectively, } \\
\text { Salmonalla typhimurium ( } 35.71 \% \text {, } 18.75 \%, 25 \% \text { and } 7.60 \%) \\
\text { respectively and Clostridium perfringens }(78.57,56.25,58.33 \\
\text { and } 61.53 \text { ) respectively respectively. It was noticed that } \\
\text { Clostridium perfringens was recorded with the highest } \\
\text { incidence. Moreovere, diarrhea become sever and have } \\
\text { offensive odur in calves occurred mainly when a combination } \\
\text { between the three bacteria (E. coli (O157), Salmonella } \\
\text { typhimurium and Cl.perfringens). It was noticed that younger } \\
\text { calves were more susceptible than the older ones. Pathoenicity } \\
\text { test in mice revealed that E. (O157) } 87 \% \text { were highly virulent } \\
\text { strains followed by Salmonella typhimurium } 75 \% \text { while Cl. } \\
\text { perfringens were lower in their virulence ( } 62.5 \%)\end{array}$ \\
\hline
\end{tabular}

Key words: Enteritis, E. coli, Sal. Typhimurium, calves, enteritis, and Cl. perfringens Introduction 


\section{بعض الدراسات عن المسببات البكتيرية للنزلات المعوية فى العجول حديثة الولادة}

\section{ازهار محمد حسن}

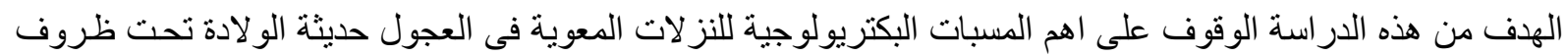

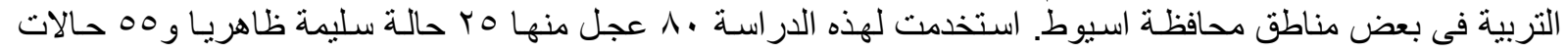

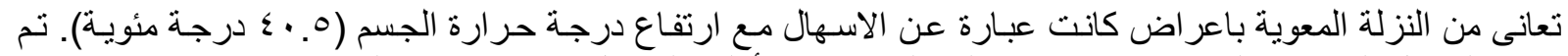

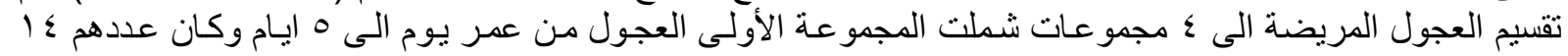

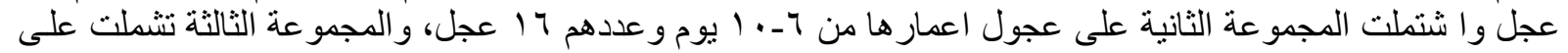

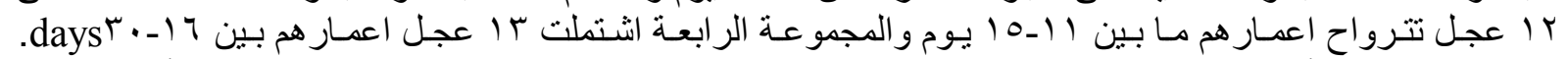

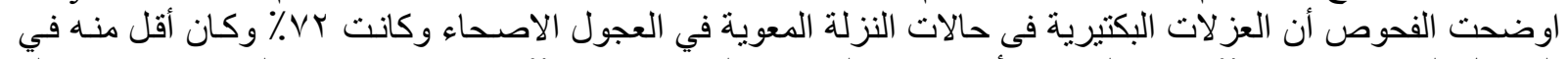

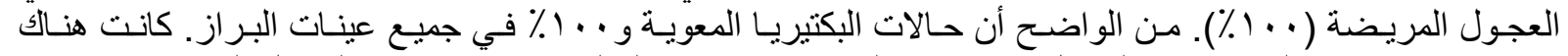

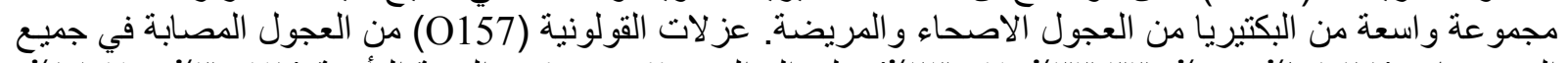

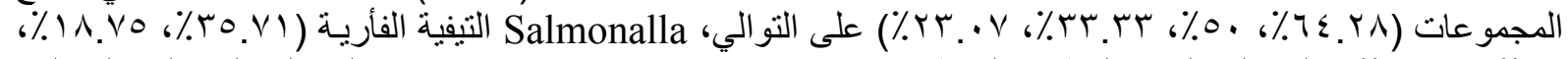

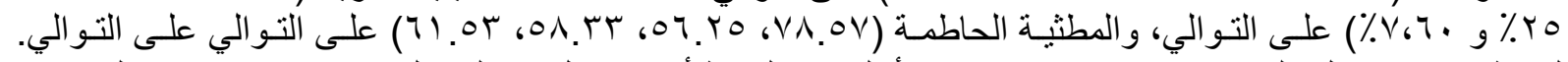

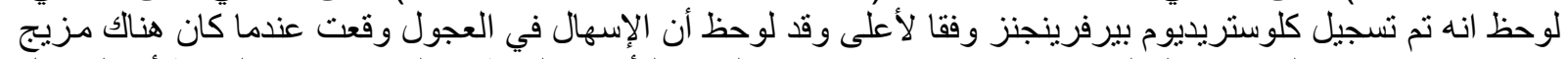

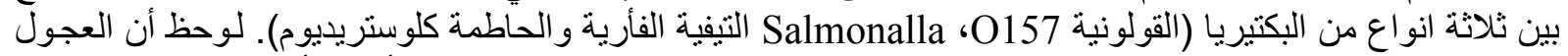

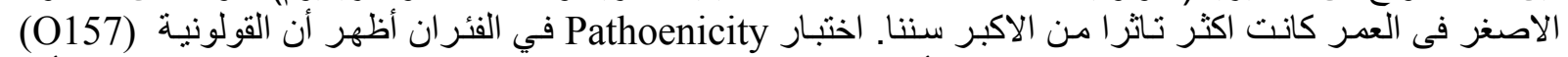

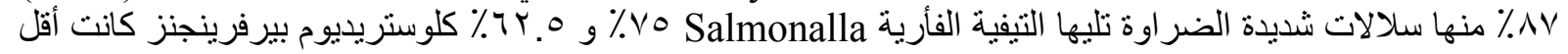

\section{INTRODUCTION}

Neonatal calf diarrhea (NCD) is a common cause of illness $(10.2 \%)$ and death in pre-weaning calves. A variety of enteropathogens have been implicated in many cases are currently idiopathic.

Enteritis in young calves considered generally to be the main hazard to calf health. Diarrhea as a symptom of enteritis is one of the major health problem in many farms associated with newly born calves which considerable number could be lost (Acress et al., 1977, Quigiey et al., 1995, Wells et al., 1996). Bispham et al. (2001) studied that within the species Salmonella Spp. there are more than 2,000 different serotypes, which include bacteria of tremendous medical and veterinary importance. The pathology of Salmonella infections can vary from mild enteritis to severe systemic salmonellosis and is largely dependent on the particular combination of serotype and host species. Most calves are affected with E. coli within the first 3 days of life. There are many types of E. coli some are normal flora; different types cause septicemia; others are invasive; Enterotoxigenic E. coli (ETEC) is the most common cause of newlyborn calf diarrhea.
Dehydration is usually severe and may cause death before diarrhea develops. The course of the disease is rapid and begins from weakness, diarrhea, dehydration, to death occurred within than 24 hours. Antibiotics rarely affect the outcome of this disease, while fluid support is critical to survival. Vaccination of dry cows and good colostrum feeding can eliminate this problem (Van Bost and Mainil, 2003). Hala et al. (2006) recorded that Salmonella spp. are an important cause of enteritis and infected calves are at risk of developing septicemia.

Infections usually occur in 5- to 14-day-old calves. Blood and casts of intestines may be seen in the feces. Calves are slow to respond to treatment and are often sick for 1 to 2 weeks. S. Typhimurium is a common cause of enteritis in newly born calves. The disease is typically localized to the intestine and characterized by acute diarrhea and abdominal pain. (Geric et al., 2006) There are several types of $\mathrm{Cl}$. Perfringens; type $\mathrm{C}$ can be a cause of diarrhea. More typically, this causes sudden onset of weakness or death. Colic or nervous system signs may be seen before death. Postmortem examination has characteristic hemorrhage in the intestines. 
Although C. difficile infection has been suggested as a cause of diarrhea and enteritis further published evidence is lacking (Alexander et al., 2012).

The objective of this study was to investigate possible bacterial causes of enteritis in apparently healthy and diseased calves under local breeding conditions. Moreover, serological identification of E.coli (O157) isolates and pathogenicity of some bacterial isolates such as $\mathrm{S}$. typhimurum and $\mathrm{cl}$. Perfingens in mice were also described.

\section{MATERIALS and METHODS}

\section{Animals:}

A total of 80 balady cow calves were investigated in this study. Calves were distributed over different areas (Dayrout, Manfolot, el- Sahal) cattle farms. These farms have been troubled and suffered from diarrhea in newly born calves. These animals were selected randomly. The samples were collected at December 20, 2011. Calves (25) were subjected to careful clinical and laboratory examinations and used as a control. These animals were fed on their mothers. The studied cases were of different sex and their ages ranged from one day - one month. Calves classified into four groups according to their age, first group included fourteen animals their age from1-5days, second group included sixteen animals of age from 6-10days, third group included twelve animals with age from 11-15days and fourth group included thirteen animals of age from 16-30days.

\section{Sampling:}

Samples from feces and intestinal contents were collected from the rectum using sterile swabs from 55 diarrheic calves showed signs of diarrhea. as well as 25 of clinical healthy calves (control). The samples from calves were collected in plastic bags and were transported refrigerated to the laboratory where were processed within 4 hours of collection. Samples were then immersed in nutrient broth about 24 hours, until bacteriological examination. Isolation and Identification of E- Coli (O157) and Sal. typhimurium (Quinn et al., 2002).

\section{E- Coli (O157)}

Samples were cultured nutrient broth and MacConkey broth and for 24 hours at $37^{\circ} \mathrm{C}$ and then a loopful was taken and cultured onto the following solid media; nutrient agar,5\% sheep blood agar and MacConkey agar. All inoculated plates were incubated at $37^{\circ} \mathrm{C}$ for 24 hours then the colonies were identified.

Serotyping of the isolated strains of EColi was done according to Edward and Ewing (1972).

\section{S. typhimurium}

Enrichment of fecal samples were processed in Rappaport broth (at $37^{\circ} \mathrm{C}$ for $18 \mathrm{~h}$ ) and Selenite brilliant green broth (at $42^{\circ} \mathrm{C}$ for 18 h) followed by incubation of the enrichment cultures on modified brilliant green agar (Oxoid) containing $120 \mathrm{mg}$ of sulfadiazine/liter.

Isolation and purification of Cl Perfringens Willis (1977): Samples from feces of calves with clinical symptoms of enteritis were inoculated into tubes of freshly prepared cooked meat medium and incubated anaerobically for 24 hours at $37^{\circ} \mathrm{C}$. A loopful of inoculated fluid medium was streaked onto neomycin sulphate blood agar with 5\% sheep blood plates for isolation of $\mathrm{Cl}$ perfringens. The streaked plates were incubated anaerobically for 24 hours at $37^{\circ} \mathrm{C}$ using a Gaspak anaerobic Jar. Suspected colonies of $\mathrm{Cl}$ perfringens that were characterized by double zone of hemolysis were sub cultured onto egg yolk agar plates. The colonies that grew only in anaerobic condition, non motile, catalase negative and lecithinase producer were picked up and purified for further identification test.

\section{Identification of Cl. Perfringens:}

Typical colonies were identified as described by Murray et al. (2003) depending on characteristic colonial morophology, hemolysis activity, gelatin hydrolysis, fermentation of glucose lactose, sucrose, maltose and mannitol, indole test, urease production, litmus milk test and lecithinase production. 
Pathogenicity of the recorded bacterial isolated in mice:

It was carried out according to Koneman et al. (1996) where 32mice, 26-28 days old were used to investigate the pathogenicity and were classified into 4 groups, each contained 8 mice which received $1 \mathrm{ml} /$ mouse of an isolate cells suspended in sterile saline containing $7.5 \times 10^{8} \mathrm{CFU} / \mathrm{ml}$ for $(\mathrm{E}-\mathrm{Coli}$
(O157), Sal. typhimurium and $\mathrm{Cl}$. Perfringens. Mice were inoculated $\mathrm{I} / \mathrm{P}$ and kept separately.Last group was kept as a control and injected only with sterile saline. All mice were kept under observation for 7 days. The number of dead mice was recorded and dead mice were subjected to bacteriological investigated for re-isolation of inoculated strains.

\section{RESULTS}

Table1: Percentages of E. coli isolated from diseased calves.

\begin{tabular}{cccc}
\hline Animal groups & Total group number & $\begin{array}{c}\text { Number of E.coli } \\
\text { isolated }\end{array}$ & $\begin{array}{c}\text { Percentages } \\
(\%)\end{array}$ \\
\hline First group & 14 (diseased calves) & 9 ( cases) & 64.28 \\
\hline Second group & 16 (diseased calves) & 8 ( cases) & 50.00 \\
\hline Third group & 12 (diseased calves) & 4 ( cases) & 33.33 \\
\hline Fourth group & 13 (diseased calves) & 3 ( cases) & 23.07 \\
\hline
\end{tabular}

Table 2: Percentages of Sal Typhimurium isolated from diseased calves.

\begin{tabular}{cccc}
\hline Animalgroups & Total group number & $\begin{array}{c}\text { Number of Sal } \\
\text { Typhimurium }\end{array}$ & $\begin{array}{c}\text { Percentages } \\
(\%)\end{array}$ \\
\hline First group & 14 (diseased calves) & 5 (cases) & 35.71 \\
\hline Second group & 16 (diseased calves) & 3 (cases) & 18.75 \\
\hline Third group & 12 (diseased calves) & 3 (cases) & 25.00 \\
\hline Fourth group & 13 (diseased calves) & 1 (cases) & 7.60 \\
\hline
\end{tabular}

Table 3: Precentages of $\mathrm{Cl}$. perfringens isolated from diseased calves.

\begin{tabular}{cllc}
\hline $\begin{array}{c}\text { Animal } \\
\text { groups }\end{array}$ & Total group number & $\begin{array}{c}\text { No of } \begin{array}{c}\text { Cl. perfringens } \\
\text { isolated }\end{array} \\
\text { First group }\end{array}$ & $\begin{array}{c}\text { Percentages } \\
(\%)\end{array}$ \\
\hline Second group & 16 (diseased calves) & 11 (cases) & 78.57 \\
\hline Third group & 12 (diseased calves) & 7 (cases) & 56.25 \\
\hline Fourth group & 13 (diseased calves) & 8 (cases) & 58.33 \\
\hline
\end{tabular}


Table 4: Pathogenicity of some enteric bacteria isolated from calves the virulence of bacteria isolated from calves, as demonstrated by the sequence of mortality in micein seven days. E- Coli (O157) were highly virulent strain $87.5 \%$ followed by Sal. typhimurium $75.0 \%$ while $C l$. perfringens were lower in their virulence $62.5 \%$.

\begin{tabular}{cccccccccc}
\hline Bacterial & \multicolumn{1}{c}{ No. of dead mice/day } & \multicolumn{3}{c}{ Total } \\
\cline { 2 - 10 } Isolates & 1 & 2 & 3 & 4 & 5 & 6 & 7 & No. & $\%$ \\
\hline $\begin{array}{c}\text { Escherichia coli } \\
\text { (O157) }\end{array}$ & 0 & 1 & 2 & 0 & 3 & 0 & 1 & $7 / 8$ & 87.5 \\
\hline $\begin{array}{c}\text { Salmonella } \\
\text { typhimurium }\end{array}$ & 1 & 0 & 1 & 0 & 1 & 3 & 0 & $6 / 8$ & 75.0 \\
\hline $\begin{array}{c}\text { Clostridium } \\
\text { perfringens }\end{array}$ & 0 & 1 & 1 & 0 & 2 & 1 & 0 & $5 / 8$ & 62.5 \\
\hline
\end{tabular}

Table 5: That percentage of enteritis were higher in diseased calves $100 \%$ which represented by 55 diseased calves classified according their age into four groups than apparently healthy calves $\mathbf{7 2 \%}$ which represented by 25 App. healthy calves.

\begin{tabular}{lccc}
\multicolumn{1}{c}{ Animals } & \multicolumn{3}{c}{ Fecal samples } \\
\cline { 2 - 4 } & No. & + ve & Percentages \% \\
\hline App. Healthy calves & 25 & 18 & 72 \\
\hline Disased calves & 55 & 55 & 100 \\
\hline Total & 80 & 73 & 91.25 \\
\hline
\end{tabular}

\section{DISCUSSION}

E. coli was isolated from from diseased calves in all groups with different percent ages $(64.28 \%, 50 \%, 33.33 \%$ and $23.07 \%)$, Sal. typhimurium $(35.71 \%, 18.75 \%, 25 \%$ and $7.60 \%$ ) and $\mathrm{Cl}$., Perfringens (78.57, $56.25,58.33$ and 61.53), As showen in (Tables and figures (1), (2), and (3) respectively).

The results presented in Table (1) showed the percentages of E.coli (O157) from diseased calves. It was noticed that First group which included 14 diseased calves and aged from one to five days old was higher than other groups, while fourth group which included 13 diseased calves and aged from 16-30 days old were lower. These results come in accordance with that of Nahed (2004). The obtained result coincided to a large extent with West (1977) who mentioned that, calf scours is often attributed to E.coli is clinically complicated by microbes like P. vulgaris. Elsa et al. (2004) reported that E.coli (O157) play an important role in 4 outbreaks of calf enteritis.

The results presented in Table (2) showed the percentages of Sal typhimurium isolated from diseased calves. It was noticed that First group which included14 diseased calves and aged from one to five days old was higher than other groups, followed by the third group, then, second group and the fourth group was the lower. These results come in accordance with Nahed (2004) and (Geric et al., 2006).

The results presented in Table (3) the percentages of $\mathrm{Cl}$. perfringens from diseased calves. It was noticed that first group was higher than other groups, $(78.57 \%)$ followed by the fourth group 61. (53\%), then, third group $(58.33 \%)$ and the second group was the lower $(56.25 \%)$. These results were not agreement with Geric et al. (2006).

It was noticed from Table (4) that the virulence of bacteria isolated from calves, as demonstrated by the sequence of mortality in mice was as follows E- Coli (O157) were highly virulent strain followed by 
S. typhimurium while $\mathrm{Cl}$. perfringens were lower in their virulence. They may be due to pathogenic nature of the strain or the presence of virulence associated plasmid or production of endo or exotoxins. These results coincided to some extent with those of Hala and Abu-Zaid (2006) who found that E- Coli (O157) and O78 Sal. enteritidis and Sal. typhimurium were highly pathogenic to mice.

\section{REFERENCES}

Acres, S.D.; Sanunders, J.R. and Radostis, O.M. (1977): Acute undiffentited diarrhea of beef calves, the prevalence of enterotoxigenic E.coli, Rota virus and other enteropathogens in cow calf herds. Can. Vet. J., 18, 113-121.

Alexander, R.P.; Henry, R.; Stämpfli, T.D.; Andrew, S.; Peregrine, L.A.; Trotz, W.; Luis, G.; Arroyo, Jon, S. and Brazier, J.S.W. (2012): $\mathrm{Cl}$. difficile PCR Ribotypes in calves, Canada Preventing Chronic Disease. J.12, 11-16

Bispham, J.; Tripathi, B.N.; Watson, P.R. and Wallis, T.S. (2001): Salmonella Pathogenicity Island 2 Influences Both Systemic Salmonellosis And Salmonella- Induced Enteritis in Calves. Infection and Immunity. asm. org doi. 69, 367-377.

Edwards, P.R. and Ewing, N.H. (1972): Identification of Enterobacteriaceae. $3^{\text {rd }}$ Ed. Burgeon publishing, Co. Atlanta,U.S.A., pp. 208-339.

Elsa, C.M.; Mariano, E.F.; Daniel, A.V.; Ana, E.; Agustín, J.V. and Winston, E.M. (2004): Necrotic enteritis in young calves Can J. Comp. Med. 32, 440-446.

Hala, S.; Ibrahim, Y. and Abu-Zaid, K.H.F. (2006): Monitoring of bacterial pollution in poultry processing plants. $4^{\text {th }}$ Sci. Cong. Fac. Vet. Med.Suez Canal Univ., Egypt.

Geric, B.; $\quad$ Carman, R.J.; $\quad$ Rupnik, M.; Genheimer, C.W.; Sambol, S.P. and Lyerly, D.M. (2006): Binary toxinproducing, large clostridial toxinnegative $\mathrm{Cl}$. difficile strains are enterotoxic but do not cause disease in hamsters. J. Infect. Dis. 193, 11431150.

Koneman, E.W.; Allen, S.D.; Janda, W.M.; Schreckenberger, P.C. and Winn, W.C. (1996): Introdudtion of Diagnostic Microbiology 5th Ed., (Lippincott Company Philadelphia U.S.A*): pp.234-239.

Murray, P.R.; Baron, E.J.O.; Pfaller, M.A.; Jorgenen, J.H. and Yolken, R.H. (2003): Manual of Clinical Microbiology $8^{\text {th }}$ Ed., Vol.1, ASM Press 456-658.

Nahed, M. and Abdel, H. (2004): Pathogenic bacteria associated with diarrhea in calves. Bacteriology,Immuunology and Mycology. M.V.Sc. thesis Fac. Vet. Med., Cairo Univ., Depart.

Quigley, J.D.; Martin, K.R.; Bemis, D.A.; Potgieter, L.N.R.; Reinemerger, C.R.; Rohrboch, B.W.; Dowlen, H.H. and Lamar, K.C. (1995): Effects of housing and colostrum feeding on serum immunoglobulin. Growth and fecal scours of Jersy calves. J. Dairy Sci., 78, 893-901.

Quinn, P.J.; Markey, B.K.; Carter, M.E.; Donelly, W.J.C. and Leonard, F.C. (2002): Vet. Microbiology and Microbial Diseases. $1^{\text {st }}$ Iowa State University Press Blackwell Science. 3rd ed., Toronto: Academic Pr, pp. 343-411.

Van Bost, S. and Mainil, J. (2003): Virulence factors and specific properties of invasive strains of E.Coli: Production of toxins. Ann. Méd. Vét., 147, 327342.

Well, S.J.; Gaber, L.P. and Hill, G.W. (1996): Healthy status of preweaned dairy heifers in United States. Prev. Vet. Med., 29, 185-199.

West, G.P. (1977): Blacks Vety. Dict., 12th Ed., 852-856.

Willis, A.T. (1977): Anaerobic bacteriology, (clinical and laboratory*): practice, Butter Worth, London, Boston, $3^{\text {rd }} \mathrm{Ed}$., pp. 131-133. 